\title{
'Hit hard, move fast and sustain action' The Replacement of the Royal Navy's Amphibious Warfare Squadron and the Rationale for HMS Fearless and HMS Intrepid
}

\author{
Ian Speller ${ }^{I}$
}

This article examines the circumstances in which the old ships and craft of the post-1945 Royal Navy's Amphibious Warfare Squadron were replaced by the new assault ships HMS Fearless and Intrepid. It analyses the impact on the requirement for amphibious forces of the change in emphasis in the late 1950s from major war contingencies to a new focus on mobile and flexible forces capable of responding to limited crises overseas. This called for a radically different type of capability than had been provided by the Amphibious Warfare Squadron and eventually resulted in a force built around two commando carriers, two new assault ships and six logistic landing ships. The article analyses alternative plans for the shape and size of the new amphibious force and examines the different design studies that resulted. It identifies a number of different ship types that were considered and demonstrates that the requirement to be able to land a joint all-arms force of up to a brigade group, supported by tanks and artillery, was key to the eventual decision to build Fearless and Intrepid and establishes the strategic rationale that underpinned the construction of these ships and demonstrates why they were built as amphibious transport docks in favour of the other design options.

Tn the late i950s the Royal Navy sought to replace the worn out ships and craft that had constituted its post-war amphibious fleet. The requirement for new construction was created by the obsolescence and approaching decrepitude of the existing force and also by new strategic circumstances that called for a rather different type of capability. The end result was a force based around two helicopter equipped 'commando carriers' and two new dock landing ships, supported by new logistic landing ships operated by the Royal Fleet Auxiliary (RFA). ${ }^{2}$ The dock landing ships HMS Fearless and HMS Intrepid were at the heart of this new capability, and continued to provide the core of Britain's amphibious fleet through until the end of the century when, finally, they were replaced by new construction. ${ }^{3}$ This article will examine why Fearless and Intrepid were built, and why they were built as they were. It will examine the different design studies that were completed, identifying the strengths and limitations of each within the context of a new strategic concept that emphasized the need to be able to deploy flexible joint (i.e. inter-service) expeditionary forces

I I am grateful for the comments of the anonymous reviewers and to the Hon. Editor for the assistance that they provided in completing this article.

2 The Logistic Landing Ships (LSLs) were initially operated by the Ministry of Transport until they were transferred to the RFA in 1970.

3 Fearless was decommissioned in 2002, three years after its younger sister Intrepid. They were replaced by LPDs Albion (2003) and Bulwark (2004). 
beyond Europe, with a particular emphasis on the Indian Ocean littoral and the Persian Gulf in the region commonly described as 'east of Suez'.

The large amphibious fleet built up by Britain during the Second World War was run down rapidly after I945, with lend-lease ships and craft returned to the United States, merchant ships converted back to trade and many old worn out vessels simply scrapped. The core of Britain's post-war amphibious fleet was provided by surviving British built vessels of various types, including the ubiquitous Landing Craft Assault (LCA), ${ }^{4}$ and by ships and craft built towards the end of the war and designed for long-range operations in the Pacific. These included the Landing Ship Tank Mark Three (LST (3)) and the Landing Craft Tank Mark Eight (LCT (8)) and these vessels, with the LCA, provided the main element of Britain's amphibious fleet through until the I960s.5 The existence of these ships and craft made it possible for Britain to maintain some form of amphibious capability at a time when very little priority was accorded to amphibious warfare, although most were left to rust in low priority reserve. Unfortunately, the ships tended to be slow, have poor sea keeping and unsatisfactory living conditions for the embarked force. They also encountered some difficulties catering for the latest generation of armoured vehicles that were larger and heavier than those which the ships had been designed for. ${ }^{6}$ The LST(3) was supposed to have a top speed of I 3.5 knots and the LCT(8) of I 2 knots. ${ }^{7}$ In practice they achieved rather less. During Operation Musketeer in November 1956 when Britain, in collusion with France and Israel invaded Nasser's Egypt, the mixed force of LSTs and LCTs surpassed all expectations by managing to maintain a speed of just eight knots between Malta and Port Said. ${ }^{8}$

The main priorities for amphibious forces at this time were training and development, to provide a cadre for expansion in the later stages of any major war and for small-scale raiding, once again, in major war. By the early i 950 s there was also a considerable emphasis placed on the requirement to maintain a military force through the landing of supplies over open beaches or to supply a civilian population in the event of the destruction of conventional port facilities. ${ }^{9} \mathrm{~A}$ small Amphibious Warfare (AW) Squadron capable of lifting a battalion group was created at Malta in I95 I and this provided a focus for training and a nucleus for expansion in war. Unfortunately it was frequently under-strength and its ships and craft, designed and built according to wartime needs and standards, did not provide a very robust or flexible capability. The shortcomings of the existing lift were all too apparent to Amphibious Warfare Headquarters (AWHQ) in London, which consistently and unsuccessfully agitated

\footnotetext{
4 See B. Lavery, Assault Landing Craft, design, construction and operations (Barnsley, 2009). 5 A number of LST(3) were converted to act as infantry assault ships through the expedient of adding LCA carried in davits and accommodating troops on the tank deck. In this role they were known as Landing Ship Tank (Assault) or simply LST (A). See The National Archives of England and Wales, Kew (hereafter, NA): NA DEFE 2/1799, Amphibious warfare ships and craft, Oct. I954.

6 I. Speller, The Role of Amphibious Warfare in British Defence Policy, 1945-56 (Basingstoke, 200I) chapter 5 .

$7 \quad$ Allied Landing Craft of World War II (London, 1985). This book is a reprint of the US Navy's Division of Intelligence Manual ONI 226, Allied Landing Craft and Ships (1944).

8 NA ADM I 16/6209, Vice Admiral M. Richmond, Naval Report on Operation Musketeer.

9 For further details see Speller, Amphibious Warfare, 86-9.
} 
for the construction of new ships and craft. ${ }^{10}$ The major problem was that while AWHQ was responsible for developing policy and maintained an amphibious training and development organization it lacked the institutional clout to force the navy to devote scarce resources either to the maintenance in commission of the small numbers of ships and craft agreed as the minimum desirable force or to proceed with the design and construction of new vessels. The navy, for its part, was reluctant to devote resources to something that it saw as a low priority. The fact that amphibious warfare was a joint task, that essentially required the navy to provide a service for the army, did not encourage Admiralty interest. ${ }^{\text {II }}$

The Suez crisis in 1956 highlighted the shortcomings of an approach that left barely enough vessels in commission to embark a battalion group. It took months to recommission enough old ships and craft to support Operation Musketeer and the delay that this imposed made a significant contribution to the political collapse that defined that operation. Equally, the decrepit nature of some of the ships and their painfully slow speed and poor endurance complicated the tactical conduct of operations. ${ }^{\mathrm{I} 2} \mathrm{By}$ this time, however, national defence priorities had already begun to shift away from a focus on major war contingencies in Europe and to place greater emphasis on the need for mobile and flexible forces capable of responding to more limited crises overseas. This process was reinforced by the debacle at Suez and led, for the first time since the war, to a renewed interest in amphibious forces within the Admiralty. This interest was given some urgency as the existing lift was approaching the end of its useful life and would need to be replaced within a few years.

By the mid-I950s it was becoming clear to British planners that nuclear stalemate made a major war in Europe unlikely and, if one did occur, it was likely to result in an early and devastating nuclear exchange. In such circumstances the role of the Royal Navy was 'somewhat uncertain', as the 1957 Defence White Paper made clear. ${ }^{13}$ However, the pressure of the Cold War and the process of European decolonization in Africa and Asia increased the potential for limited conflict overseas. Even before Operation Musketeer the navy had begun to revise its priorities and had identified a new role in providing mobile and flexible forces for use in limited war and crisis management. This implied a reduced emphasis on major war in Europe and a new focus on expeditionary capabilities for contingencies further afield. The change in approach was reflected in a new concept for the Future Role of the Navy, presented to the Chiefs of Staff in July 1956, that argued that the navy would protect British interests overseas through the deployment of a task-force built around an aircraft carrier, a commando equipped helicopter carrier, a cruiser and four destroyers, all based at Singapore. ${ }^{14}$ These new priorities were reinforced by failure of the old

Io AWHQ, formerly Combined Operations Headquarters, was a joint organization with responsibility for the development of amphibious training and techniques under the Chief of Amphibious Warfare and responsible directly to the Ministry of Defence.

I I See Speller, Amphibious Warfare, passim.

I 2 NA ADM i i6/6209. See also I. Speller, 'The Suez Crisis (Operation Musketeer, November I956) in T. Lovering (ed.), Amphibious Assault. Manoeuvre from the sea from Gallipoli to the Gulf (Rendlesham, 2007), 42 I-36.

I 3 British Parliamentary Papers, (hereafter, BPP), BPP Cmnd.r 24., Defence: Outline of future policy 1957 (London, I957)

I4 NA DEFE 5/70, COS (56) 280, 20 Jul. I956. 
approach at Suez and were codified in the Autumn Naval Rethink of I957. ${ }^{\text {Is }}$

An early result of this new focus on amphibious forces was the Admiralty's decision in 1956 to convert a light fleet carrier into a helicopter carrier for amphibious purposes. ${ }^{16}$ The decision reflected recent developments in the United States and AWHQ had, for some time, been pressing for such a conversion. ${ }^{17}$ Operation Musketeer provided an opportunity to test the idea in combat, and on 6 November I956 the marines of No. 45 Commando were landed at Port Said by helicopters operating from HMS Ocean and HMS Theseus. ${ }^{18}$ This success was followed by the conversion in 1959 of the Centaur class aircraft carrier HMS Bulwark into a helicopter equipped 'commando carrier'. The vessel recommissioned in its new role in January I 960 and was followed two years later by its sister ship, HMS Albion.

The commando carriers were designed to carry, support and maintain under operational conditions a battalion sized Royal Marines Commando unit and could, if necessary, embark an additional Commando unit and a brigade headquarters for a short period of time. They could land the embarked force using their own dedicated squadron of medium lift helicopters, initially I 6 Westland Whirlwinds. ${ }^{19}$ As converted aircraft carriers they had a speed and range far in excess of the ships of the old AW Squadron and proved to be extremely versatile assets in a wide range of circumstances, particularly once the more capable Wessex replaced the Whirlwind and the Commando units were reinforced with additional administrative and support elements and joint assets, including light Io5-mm guns from 29 Commando Regiment, Royal Artillery. What the commando carriers could not do, however, was to land heavy vehicles or armour in the assault and it was the belief that this capability continued to be important that determined the nature of the replacement for the worn out ships of the AW Squadron.

There were two different but related elements to the question of replacement amphibious ships and craft. There was assault shipping, designed to land troops in the initial stages of any operation and needed to replace the ageing and inadequate ships of the AW Squadron. In addition there was also a need to cater for logistic shipping designed to bring follow-on forces, reinforcements and supplies after the initial assault, and also for transport duties in peacetime. The latter role was currently undertaken by a fleet of old LST(3)s that had been transferred to the army for that purpose. Manned by civilian rather than naval crews they were known as WD (War Department) LSTs. In a crisis they could be supported by naval LSTs and LCTs brought out of reserve, by requisitioned merchant shipping, or by conventional naval vessels operating as makeshift landing ships. ${ }^{20}$ In common with their counter-parts

Is E. J. Grove, Vanguard to Trident. British Naval Policy Since World War II (London, 1987), 2 IO.

I6 NA DEFE $5 / 70 \mathrm{COS}(56) 280,20 \mathrm{Jul}$. I956.

I7 NA DEFE 2/I90I, docket AW 558/55, folio 39, note from AWHQ to the Secretary of the Admiralty, 20 Jul. I955.

I 8 The Marines were landed in an area of the beach that had already been secured by the seaborne force. For further details see NA ADM 202/455, Brigadier R. W. Madoc, 3 Commando Brigade Royal Marines - Operation Musketeer Report.

I9 NA DEFE 5/85, COS (58) 219, I8 Sept 1958. Royal Marines Museum, Eastney, AWHQ Information Letter No. 9, 1958 .

$20 \mathrm{NA} \mathrm{DEFE}_{4} / \mathrm{IO}_{3}$, SRC (57) Io at annex to COS (58) $3 \mathrm{rd}$ meeting, 9 Jan. 1958 
in the AW Squadron, the WD LSTs were approaching the end of their useful lives.

A necessary preliminary to deciding on the nature of any replacement shipping was some agreement on the likely need. Initial studies in the aftermath of Operation Musketeer were based on a Joint Planning Staff (JPS) report that identified the short-term requirement to be the ability to contribute to an allied operation by being able to land an assault force of two battalions with light support in the eastern Mediterranean within 28 days. ${ }^{21}$ The size of the assault force was determined by the perceived limitations of the existing naval lift and was thus more useful as a reminder of current constraints than as a reasonable basis for long-term planning. The Chief of Amphibious Warfare, Major General James Moulton RM, argued in favour of planning for the employment of a full brigade group, with the assaulting element of two battalions and two armoured squadrons catered for in naval shipping and the remaining force carried in logistic lift, as had been the case during Musketeer. ${ }^{22}$ The army and navy supported this approach and, although the Royal Air Force (RAF) were much less convinced of the need for a force of this size, in January 1958 the Chiefs of Staff agreed that the lift required for an amphibious operation would be for a commando or battalion at light scales at immediate notice and for a full brigade group, with two battalions/commandos and some armour in the assault, within 28 days. ${ }^{23}$ Unfortunately, it proved to be impossible to provide this economically using ships and craft currently available and so the requirement was later relaxed to the need to land a small lightly supported force within i 8 days or for a full brigade group, with armour and supporting arms, within 35 days. ${ }^{24}$

In March 1959 Major General Moulton summarized AWHQ's appreciation of the long term requirement for amphibious shipping. ${ }^{25} \mathrm{He}$ noted that recent events pointed to the need for 'speed of action, for increasing independence of colonial bases and terminals, and for the ability to avoid the Suez air/sea barrier', the latter point referring to the barrier to British military air and sea movement formed by unfriendly states in the Middle East. He also suggested that, while close cooperation with the United States was to be expected, in conflicts short of war there were liable to be differences of interest and that therefore 'the more balanced and self-reliant our forces, the better will we be able to further British interests, whether in an allied operation or independently.' In his opinion air and sea lift and stockpiling represented complementary methods of projecting British influence. Airlift provided the best means of moving troops over long distances, but sea lift was required to carry the heavy tonnages and large numbers of vehicles required for sustained operations, whether they came from the UK or from local stockpiles. He also noted that the tonnages required to establish a forward air terminal, particularly aviation fuel, were best handled by sea.

AWHQ concurred with the War Office view that the standard brigade group with supporting arms would be the basic formation for seaborne operations, emphasizing

2 I 'Light support' included one battery of field artillery, one squadron of armour and a brigade headquarters. NA DEFE 4 /100, COS (57) 76 th meeting, 3 Oct. I957.

22 Ibid.

23 NA DEFE $4 / \mathrm{I}_{3}, \mathrm{COS}(58)$ 3rd meeting, 9 Jan. 1958.

24 NA DEFE $5 / 88, \operatorname{COS}$ ( 59 ) 333 , report by the JPS, Io Feb. 1959.

25 NA DEFE $5 / 90 \mathrm{pt}$ I, COS (59) 67, Long term requirement for amphibious shipping, 20 Mar. I959. 
the continuing need for a force that could 'hit hard, move fast and sustain action' as the most effective means of 'settling trouble at least cost in casualties, prestige and time'. Potential enemies were likely to be armed with modern weapons, including armour. The possibility that an enemy might have nuclear weapons was also noted and Moulton suggested that, to avoid nuclear blackmail, Britain needed to develop a 'fast moving, hard-hitting technique which will confront the enemy with technically superior forces and limit temptation to use atomic weapons, should he have them'. ${ }^{26}$

AWHQ thus favoured fast moving, hard-hitting amphibious forces based on a standard army brigade group. To this end they supported the development of new, faster and more flexible techniques in amphibious operations, seeking to identify synergies between amphibious and airborne forces. This was to bear fruit in the new seaborne/airborne concept, unveiled in I96 I and eventually incorporated into a new Manual of Joint Warfare in $1964 .{ }^{27}$ In terms of the requirement for new ships and craft they suggested that the choice lay between the maintenance of two commando carriers or a mixed lift incorporating one commando carrier plus some LSTs or a vessel similar to the wartime Landing Ship Dock (LSD). The latter option was favoured as an all-carrier force would not be able to transport and land the vehicles and heavy equipment required by the brigade group. The Admiralty were invited to finalize design studies for a naval landing ship for the assault and to make provision for an LSD or LST in the 1960/6r estimates.

It was not the first time that AWHQ had invited the Admiralty to undertake design work and to proceed with the construction of amphibious ships. They had done so on a regular basis since 1945, always to no avail. ${ }^{28}$ This time, however, things were different. Amphibious operations were now at the heart of the Admiralty's plans for a navy focused on the need to project power east of Suez. The Royal Navy was reinventing itself as a tool for the projection of British power overseas and amphibious forces played an important part in this. The process began under First Sea Lord (and former Chief of Combined Operations) Admiral Lord Louis Mountbatten and continued to gain momentum so that by 1962 the Statement on the Naval Estimates justified all types of naval vessel, from aircraft carriers to minesweepers and submarines, through reference to their utility in support of amphibious operations and made no mention of any other role. ${ }^{29}$ Amphibious forces also had powerful backers within Whitehall. Harold Watkinson, Minister of Defence from 1959 to 1962 , was a notable supporter..$^{3 \circ}$

Mountbatten's successor as First Sea Lord, Admiral Sir Charles Lambe, was keen to portray amphibious forces as being part of a joint capability and, in 1959, proposed that the three services should form a Joint Services Seaborne Force capable of lifting a brigade group and built around two commando carriers, and a mixture of RN LSTs, WD LSTs, a troopship and a motor transport ship. The force would be based

\footnotetext{
26 Ibid.

27 For the seaborne/airborne concept see NA DEFE 5/I I4, COS (6I) i 80, Seaborne/Airborne/ Land Concept, 8 Jun. I96 I and NA DEFE 2/2074, Joint Warfare Staff, 3 I Jul. I 962 . For the Manual of Joint Warfare see NA DEFE 73/I, Manual of Joint Warfare. Volume I: Concept, planning and control of operations.

28 See Speller, The Role of Amphibious Warfare, passim.

29 BPP Cmnd 1629, Explanatory Statement on the Navy Estimates 1962-1963, (London, 1962).

30 H. Watkinson, Turning Points: A record of our times (Salisbury, I986).
} 
at Aden and held at 14 days notice to move. It would provide a mobile and flexible capability to intervene in a wide range of different circumstances, with the security of Kuwait prominent. Lambe argued that the idea offered a 'mobile force of good striking power and flexibility' and 'a promising opportunity of avoiding the wasteful process of setting up expensive shore installations in successively threatened areas where security of tenure is doubtful'. ${ }^{31}$ The force would require an additional I,700 naval personnel and some cost for the commissioning of the second commando carrier and the refit and air-conditioning of LSTs. Unfortunately, the Chief of the Defence Staff, Marshal of the RAF Sir William Dickinson, was far from convinced that the proposal offered real value for money and the Chiefs of Staff agreed that, in the short-term, it was not worth pursuing the idea. ${ }^{32}$

The concept of a Joint Services Seaborne Force did not go away however. In May 196 I the First Sea Lord, Admiral Sir Caspar John, developed a case designed to cater for a scenario where the British possessed no bases east of Suez except in Australia. In these circumstances he proposed to deploy military strength from a Joint Services Seaborne Force able to put ashore a balanced brigade group, supported by aircraft carriers. He went further than Lambe, arguing that there should be two powerful amphibious groups, each capable of lifting a brigade group, so that, with rotation, one would always be available. ${ }^{33}$ John was at pains to stress the inter-service nature of this force, which would embark army personnel and equipment and could be supported by land based aircraft and airborne forces when operating within range of a friendly base. His concept, requiring four commando carriers, four assault ships and six aircraft carriers was never likely to gain approval from the other services given the excessive cost implications. The navy did, however, gain approval for the provision east of Suez of one Amphibious Group and the deployment there of both commando carriers and also the two new assault ships that had, by then, been approved. ${ }^{34}$

Amphibious forces were therefore at the heart of the navy's plans for the future. ${ }^{35}$ The need for replacement shipping was embraced by the Admiralty and accepted by the other services. The army were eager to ensure that any new ships should be able to accommodate the full range of equipment required by a standard brigade group, including armour and artillery. The brigade group was recognized to be both the largest force liable to be available at short notice and also the smallest force capable of independent operations against 'moderate' opposition. The RAF preferred to focus on operations against weaker opposition, where light forces alone would suffice, reflecting their preference for airborne and air transported forces. However, faced with the opposition of the other two services they did not press the issue at this stage.

The JPS were given the task of developing detailed proposals for replacement amphibious ships and craft. Before they did this an Admiralty and AWHQ study group undertook a technical examination of the issue..$^{36}$ This examination was based

3 I NA DEFE 5/92, COS (59) I 37, Joint Services Seaborne Force, I 2 Jun. I959. NA DEFE 4/I I 9, $\operatorname{COS}(59) 38$ th mtg, item 3, I6 Jun. I959.

32 NA: DEFE 4/I i9, COS (59) 38th mtg, item 3, I6 Jun. I959.

33 NA ADM 205/192, Presentation of Alternative Long-term Naval Programme, i7 May I96I.

34 NA DEFE 7/2235, COS (6I) 499, digest of report of COS (62) I. NA CAB I 3 I/27, D (61) Ist mtg, I 2 Jan I 962.

35 Grove, Vanguard to Trident, chapter 7.

36 NA DEFE 5/86, COS (58) 254, I3 Nov. 1958. 
on the assumption that there was no requirement for sea-borne assault forces solely for major war purposes and that the commando carrier would suffice for internal security operations overseas. They did not foresee involvement in limited war without allies, except in the Arabian Peninsula. In contrast to previous studies, which focused on the confined waters of the Mediterranean, the need to be able to conduct ocean passages of 2,000 to 3,000 miles was stressed, as was the requirement for speed. The largest formation liable to be available for a seaborne assault was the brigade group, perhaps supplemented by an airborne brigade, and thus the examination based its findings on the need for naval shipping to cater for the assault elements of a standard brigade group, specifically; two battalion groups at assault scales, two field batteries, two squadrons of armour and a brigade headquarters. Follow-on forces would arrive in civilian manned shipping and this was the subject of a separate enquiry.

The study group identified five alternatives:

a) LCT(9) This was an updated version of the existing LCT(8). Sketch designs suggested it would carry 60 men and six tanks or I 3 3-ton equivalents at a speed of up to I 2 knots. It did not possess the ocean-going capability intended and, as it lacked accommodation for any troops beyond the vehicle crews, such craft would need to be supplemented by troopships or similar vessels.

b) Bow-loading LST This ship, similar in design to existing LSTs, was to embark half a battalion group including 465 troops, eight tanks, four self-propelled guns and 27 vehicles and had to be able to land them on a beach gradient of I in I 20 . Two designs were investigated, $\mathrm{BL} / \mathrm{C}$ and $\mathrm{BL} / \mathrm{D}$, with an estimated speed of $\mathrm{I} 4$ knots and I 6 knots respectively. It was not believed that they would be able to design a ship with a sustained speed in excess of I 6 knots. To land forces on beaches shallower than I in I 20 a long causeway, too long to be carried on a single ship, would need to be used. Given the vulnerability of such a large ship it would probably not be acceptable to beach it in the early stages of an assault and, therefore, Duplex Drive (DD) equipment would be required if tanks were needed ashore.

c) Stern-loading LST The stern loader shared many of the characteristics of the bow-loader but, in lacking bow doors, it had improved speed and sea keeping gained at the cost of not being able to beach itself. Instead forces would be launched from the stern of the vessel using DD equipment or some form of landing craft or ferry. The possibility of using helicopters to land troops and equipment was identified. The difficulty in landing heavy vehicles, and the delays inherent in a ferry-system of landing meant that this type was rejected.

d) Amphibious Transport Dock (ATD) Similar in design to an LSD this vessel combined good range and passage speed with the ability to land troops and vehicles using landing craft carried in its stern dock. It did suffer from some of the problems of the ferry system but, unlike the stern-loading LST, could embark forces within its protected dock, making it far less dependent on good weather to unload. It could also load two landing craft simultaneously. Large vessels, such as design study DL/A (I I, 500 tons) were considered to be too big for British purposes, representing a dangerous case of putting 'too many eggs in one basket'. A smaller vessel, capable of lifting two-thirds of a battalion group, was preferred and this was catered for in design study DL/B (8,000 tons).

e) US built-ships and craft The purchase of US ships was considered, but in 


\begin{tabular}{|c|c|c|c|c|c|c|}
\hline Design & $\begin{array}{l}\text { Deep } \\
\text { displace- } \\
\text { ment (tons) }\end{array}$ & $\begin{array}{l}\text { Max. } \\
\text { speed }\end{array}$ & $\begin{array}{l}\text { Dimensions } \\
\text { length } x \\
\text { breadth }(f t)\end{array}$ & Draught & $\begin{array}{l}\text { Ship's } \\
\text { complement }\end{array}$ & Military load \\
\hline SL/A & 5,380 & 24 knots & $400 \times 54$ & $\mathrm{I} 4 \mathrm{ft} \mathrm{IO}$ in & I5O & $\begin{array}{l}465 \text { troops, } 8 \text { tanks, } \\
4 \text { SP guns and } 273 \text {-ton } \\
\text { equivalents }\end{array}$ \\
\hline SL/B & 3,970 & I7 knots & $390 \times 52$ & I Ift $8 \mathrm{in}$ & 109 & $\begin{array}{l}465 \text { troops, } 8 \text { tanks, } \\
4 \text { SP guns and } 273 \text {-ton } \\
\text { equivalents }\end{array}$ \\
\hline SL/C & 4,750 & 20 knots & $390 \times 52$ & ${ }_{1} 3 \mathrm{ft} 5$ in & 109 & $\begin{array}{l}465 \text { troops, } 8 \text { tanks, } \\
4 \text { SP guns and } 273 \text {-ton } \\
\text { equivalents }\end{array}$ \\
\hline $\mathrm{BL} / \mathrm{C}$ & 3,920 & Is knots & $400 \times 55$ & gft 7 in & 109 & $\begin{array}{l}465 \text { troops, } 8 \text { tanks, } \\
4 \text { SP guns \& } 273 \text {-ton } \\
\text { equivalents }\end{array}$ \\
\hline BL/D & 4,670 & I7 knots & $400 \times 55$ & I Ift $\mathrm{I}$ in & 109 & $\begin{array}{l}465 \text { troops, } 8 \text { tanks, } \\
4 \text { Sp guns and } 2 \text { I } 3 \text {-ton } \\
\text { equivalents }\end{array}$ \\
\hline $\mathrm{DL} / \mathrm{A}$ & I I , 500 & 2 I knots & $500 \times 82$ & I $8 \mathrm{ft} 3$ in & 385 & $\begin{array}{l}\text { I } 80 \text { troops, I } 8 \text { tanks, } \\
8 \mathrm{SP} \text { guns and } 603 \text {-ton } \\
\text { equivalents }\end{array}$ \\
\hline $\mathrm{DL} / \mathrm{B}$ & 8,000 & 23 knots & $450 \times 70$ & $16 \mathrm{ft}$ & 289 & $\begin{array}{l}700 \text { troops, I } 2 \text { tanks } \\
6 \mathrm{SP} \text { guns and } 403 \text {-ton } \\
\text { equivalents }\end{array}$ \\
\hline
\end{tabular}

Key: $\quad$ SL/A, SL/B, \& SL/C = Stern Loading LST

$\mathrm{BL} / \mathrm{C} \& \mathrm{BL} / \mathrm{D}=$ Bow Loading LST

DL/A \& DL/B = Amphibious Transport Dock

general they were viewed as being larger than was suitable for the British force. It was noted that the latest US LSTs had good speed and sea keeping, but that they lacked the necessary beaching characteristics. It was also suggested that Americanbuilt ships had the disadvantage that they might come with 'diplomatic strings' attached to their use. ${ }^{37}$

It was clear that different ship types offered different strengths. The ATD promised good speed, range and sea keeping, allowing it to keep up with the commando carrier. Unfortunately, it could only land non-DD vehicles by ferry, an inherently time consuming business. The bow-loading LST, on the other hand, was slower but could land its vehicles directly onto the beach, although doing so in the early stages of an assault was not recommended due to its vulnerability to enemy fire. Such ships offered the best way of meeting army requirements for the lift and unloading of all forms of vehicles. However, if the assault lift was composed entirely of LSTs this would cause problems when operating with the commando carrier or with US forces which, it was noted, adopted a concept where the assault element travelled in fast helicopter landing ships (LPH) and ATDs (designated LPDs in US service), with follow-on forces arriving in slower LSTs. With regards to the requirement 
for a HQ ship they believed that this vessel would also need to be able to carry vehicles (including those required by the land force $H Q$ ) and that the requirement could be met in the same hull as the assault ships. Overall, the technical examination concluded that the choice appeared to lie between design studies BL/D and DL/B. Sketch designs for the different ships considered by the study are shown at figures (i) to (vii). $\cdot^{8}$ See appendix A.

The examination reflected a noticeable change in thinking about the assault shipping. The requirement for speed and a capability to conduct ocean passages reflected the limited war role and an emphasis on operations in support of policy beyond Europe, rather than short-ranged assaults in home waters. The continued emphasis on a balanced landing force and, in particular, the need to land armour in the assault played a key role in raising design challenges and also costs. The need to balance the incompatible demands of speed, payload and beaching/unloading ability made inevitable a compromise on one or more of these characteristics.

The focus on being able to land a balanced military force of up to a brigade group reflected current thinking about the likely scale of operations in situations short of global war and this was reflected in the key study of 'British Strategy in the Sixties' undertaken in 196r. For the purposes of that study it was accepted that Britain would not attempt to intervene in the face of heavy opposition requiring a fullscale assault without the assistance of allies. However, British forces might have to intervene in circumstances where the points of entry were in hostile hands. ${ }^{39}$ The Admiralty therefore proceeded on the basis that they needed to be able to land a balanced brigade group, against opposition if necessary. The army view was that it was difficult to visualize operations where a force of less than one brigade group would be required to make a successful assault against opposition and that it was vital that any landing force should include armour and artillery..$^{\circ}$ In April 1959 the Chief of the Imperial General Staff, General Sir Francis Festing rejected RAF suggestions that air power could substitute for friendly armour, stating that:

We must retain the ability to carry out an amphibious assault with balanced forces ... it would be unrealistic to assume that in all cases an assault could be carried out without tanks; air support could not always be guaranteed and an enemy possessing only a few tanks could seriously embarrass, if not actually defeat, a landing which had no tanks in the assault. ${ }^{4}$

It is worth noting that in May $194^{2}$ Festing had commanded the $29^{\text {th }}$ Infantry Brigade who landed at Diego Suarez during Operation Ironclad, the Allied invasion of Madagascar, as part of a balanced force including tanks and artillery. ${ }^{42}$

The Admiralty/AWHQ technical examination was followed, in May 1959, by the JPS Long Term Study. Requested by the Chiefs of Staff in February 1958, this paper was supposed to report on the long-term world-wide operational requirement for amphibious lift. Unfortunately the Joint Planners had not been able to agree on the

38 Ibid.

39 NA DEFE 5/I 23, COS (62) I, British Strategy in the I960s, 9 Jan. I 962.

40 For example see NA DEFE $4 / \mathrm{IO}_{3}$, COS ( 58 ) $3 \mathrm{rd} \mathrm{mtg}$, 9 Jan. I 958.

4I NA DEFE 4/I I7, COS (59) 24th mtg, 7 Apr. I959, item 4.

42 See T. Benbow, 'The British invasion of Madagascar: Operation Ironclad, May 1942' in Lovering (ed.), Amphibious Assault, I07-22. 
assumptions upon which to base this enquiry and so instead they merely identified alternative means of providing a long term capability for amphibious operations, leaving the Chiefs of Staff to decide between a range of alternatives. ${ }^{43}$ It is perhaps not surprising that the JPS could not agree. While the army and the navy remained sure of the need for assault shipping to land a balanced brigade group, including tanks and artillery, the RAF was far from convinced. The view from within the Air Ministry was that amphibious forces were not required for cold war or internal security duties, for which they favoured airborne forces. They believed that the requirement for an amphibious assault was restricted to limited war operations and that the maximum lift that should be contemplated was for only two battalions lightly equipped, a force rather similar to that which could be air lifted. ${ }^{44}$ Having joint planners does not always ensure joint priorities.

Nevertheless, with the army, navy and AWHQ all focused in the need to embark and land a balanced force, the JPS built on the principles established in previous studies and remained focused on the need to be able to put ashore in an assault, within 28 days, a brigade group of three battalions, a brigade headquarters, two squadrons of tanks and two batteries of field artillery. They noted that it was no longer appropriate to give 'undue emphasis' to the eastern Mediterranean and identified the problem posed by the Middle East 'air/sea barrier' formed by unfriendly states unlikely to permit over-flight and by the potential closure of the Suez canal. Planning proceeded on the basis that Britain could not count on getting the use of a port or airfield in the early stages of an operation and that it would be unsound to rely on the immediate availability of adequate reception facilities.

The speed and flexibility of helicopter and airborne forces was recognized as a particular advantage for limited and cold war operations, but their inherent lack of organic heavy support was identified as placing them at a disadvantage against an enemy in prepared positions or equipped with armoured fighting vehicles. The JPS did not envisage a requirement to conduct an assault against a heavily defended coastline, but did believe that an assault lift should be retained that permitted the close and intimate support of guns and armour. Some consideration was given to the use of tactical nuclear weapons as one means of overcoming prepared defences, and thus reducing the requirement for organic armour support, but obvious political and practical problems made this an unattractive proposition. ${ }^{45}$

The report considered four main types of ship, based on the design studies from the Admiralty/AWHQ technical examination. For the assault they looked at the commando carrier, the ATD ${ }^{46}$ and the LST(A).47 For the follow-up they looked at an improved version of the WD LST. In common with earlier reports, the use of Royal Navy shipping for both the assault and follow-up was rejected as being too expensive. Two alternative means of meeting the 28 -day time scale were suggested:

43 NA DEFE 4/ i 8 , JP (58) 24, Report by the JPS, i May 1959; at annex to COS (59) 32nd Meeting, item 2, 26 May I959.

44 NA: AIR 8/2235, brief for the CAS by DASB, 6 April I959; also see brief for CAS for COS meeting on 26 May I959.

$45 \mathrm{JP}(58) 24$.

46 Design studies DL/A (large ATD) and DL/B (small ATD).

47 Design study BL/D. 


\begin{tabular}{|c|c|c|c|c|}
\hline & Case C & Case D & Case E & Case F \\
\hline Commando Carrier & I & 2 & I & 2 \\
\hline ATD & small or 2 large & 2 small & - & - \\
\hline LST(A) & - & - & 5 & 4 \\
\hline WD LST & 9 & 9 & 9 & 9 \\
\hline RN manpower* & 900 & $\mathrm{I}, 390 / 900$ & 550 & $\mathrm{I}, 230 / \mathrm{I}, 530$ \\
\hline Civilian manpower (WD & 585 & 585 & 585 & 585 \\
\hline Capital cost & $29.4 \mathrm{~m}$ & $30.8 \mathrm{~m}$ & $29 \mathrm{~m}$ & $32.6 \mathrm{~m}$ \\
\hline
\end{tabular}

Case A HMS Bulwark plus either three small or two large ATDs

Case B HMS Bulwark plus a second commando carrier and two small ATDs

In both cases nine WD LSTs would be needed on either side of the barrier for follow-on forces or, to save money, a total of nine WD LSTs could be based on whichever side of the barrier they were most likely to be needed. Case B provided the possibility of basing on either side of the barrier a balanced force consisting of one commando carrier, one ATD and nine WD LSTs. Unfortunately, with only two ATDs some vehicles intended for the assault would have to be carried in the followup and up to 203 -ton equivalents would be lost from the overall lift unless larger and more expensive ATDs were considered.

The JPS also considered cheaper alternatives based around the ability to conduct an assault at less than brigade group strength within 28 days with the capability to increase the assault lift to brigade scale at greater notice. Extending the time scale allowed for the use of slower LSTs, and for the maintenance of fewer WD LSTs either side of the barrier (nine in total)..$^{8}$ Four options were advanced, see table $2 .{ }^{49}$

The ATD was preferred to the LST(A) as it was faster and better able to land tanks given that the LST(A) was too large and vulnerable to beach in the early stages of an assault. The JPS therefore preferred cases $\mathrm{C}$ and $\mathrm{D}$ to $\mathrm{E}$ and $\mathrm{F}$ and, between $\mathrm{C}$ and $\mathrm{D}$, they preferred the latter.

The JPS also devised options for an assault force that was not capable of lifting a brigade group, with a brigade size force only being built up subsequent to the assault. Two cases were advanced, see table 3 .

Option G was identified as offering the best force for conducting an assault over a beach as it provided for a more balanced landing force. Option $\mathrm{H}$, with its two commando carriers, offered advantages of speed and flexibility in situations where a beach landing was not required, but was limited in its ability to land vehicles and heavy equipment.

The requirement for a headquarters ship for the Naval Assault Group commander and the Assault Brigade Commander was also examined. The latter would deploy ashore once the beachhead had been secured and there was an advantage in the Brigade HQ vehicles being deployed with the HQ prior to this eventuality. Given

48 JP (58) 24.

49 Capital costs and manpower costs in all cases (including Case G and H) excluded those for Bulwark which had already been accounted for in Admiralty plans. 


\begin{tabular}{lcc}
\hline Table 3 & Alternative options for assault shipping (ii) & \\
& Case $G$ & Case $H$ \\
Commando Carrier & $\mathrm{I}$ & 2 \\
ATD & 2 small & $\mathrm{I}$ \\
LST(A) & - & - \\
WD LST & 9 & 9 \\
RN manpower & 600 & $\mathrm{I}, 090 / \mathrm{I} 390$ \\
Civilian manpower (WD) & 585 & 585 \\
Capital cost & $24 . \mathrm{Im}$ & $25.5 \mathrm{~m}$ \\
\hline
\end{tabular}

this, the ATD represented a better platform for the HQ than did the commando carrier.

Of all the options presented by the JPS the RAF were inclined to favour Case $\mathrm{H}$, the closest to their own concept of light but quick intervention forces..$^{\circ}$ The army, on the other hand, favoured Case $\mathrm{C}$ or Case $\mathrm{D}$ as provision of two or more ATDs offered the best means of landing armour and heavy equipment in the early stages of any operation. ${ }^{\text {II }}$ After discussion the Chiefs of Staff agreed that detailed design studies should start on an ATD and a WD LST and that the Centaur class light fleet carrier HMS Albion should be earmarked for a possible conversion to a commando carrier. Case C and Case D were accepted as suitable hypothetical bases to carry out detailed costings. ${ }^{22}$ These costings were completed by November 1959. In order to maintain in service the required number of ships additional vessels would need to be maintained in operational reserve. The full requirement for Case $\mathrm{C}$ was thus for two commando carriers, four ATDs and nine WD LSTs. Similarly, Case D required three commando carriers, three ATD and nine WD LSTs. As an alternative to this expense the Admiralty prepared cases $\mathrm{C}+$ and $\mathrm{D}+$. Case $\mathrm{C}+$ provided for one commando carrier and one ATD in commission and two ATDs in reserve. Case D+ provided for one commando carrier and one ATD in commission and one each in reserve (see table 4).

In December 1959 the Minister of Defence, Harold Watkinson, submitted the new naval construction programme to the Defence Committee. Admiralty Long Term Costings catered for an amphibious force based on Case D+. The first new assault ship (ATD) was planned to complete in $1964 .{ }^{53}$ Watkinson was a firm believer in the value of amphibious forces as an important way of bringing mobility and flexibility to Britain's armed forces. He pressed his cabinet colleagues to approve two new assault

\begin{tabular}{lcccc}
\hline Table 4 & Alternative options for assault shipping (iii) & & \\
& Case C & Case D & Case C+ & Case D+ \\
Commando carrier & 2 & 3 & $\mathrm{I}$ & 2 \\
ATD & 4 & 3 & 3 & 2 \\
WD LST & 9 & 9 & 9 & 9 \\
Additional RN Manpower & $\mathrm{I}, 900$ & 2,600 & $\mathrm{I}, \mathrm{I} 25$ & 850 \\
Annual maintenance cost & $£_{\mathrm{I} .7 \mathrm{Im}}$ & $£_{3.08 \mathrm{~m}}$ & $£_{0.56 \mathrm{~m}}$ & $£_{0} .62 \mathrm{~m}$ \\
Capital expenditure & $£_{45} .07 \mathrm{~m}$ & $£_{4} 8.58 \mathrm{~m}$ & $£_{34.56 \mathrm{~m}}$ & $£_{3} \mathrm{I} .25 \mathrm{~m}$ \\
\hline
\end{tabular}

50 NA AIR 8/2245

5 I NA DEFE 4/ I 18, COS (59) 32nd meeting, item 2, 26 May I 959.

52 Ibid.

53 NA CAB I 3 I/22, D (59) 40, 22 Dec I959, memo by Minister of Defence. 
ships, arguing that their 'qualities of speed, seakeeping and endurance will transform the effectiveness of our amphibious capabilities'. ${ }^{44}$ Having secured agreement for the conversion of HMS Albion he then pushed to have both commando carriers in commission, rather than keeping one in reserve. The Chiefs of Staff backed this decision and Cabinet approval was gained in February 196I when the Chancellor of the Exchequer removed Treasury objections. The Chancellor also agreed that the construction of the first ATD, described as a Seaborne Support Ship (Assault Ship), should proceed. ss

The plan to build a new assault ship to replace the AW Squadron was announced in the 1961 Navy Estimates. ${ }^{56}$ The design for this ship was approved by the Board of Admiralty in March I96I. The ship was to be I2, I00 tons deep displacement 57 with a trials speed of $2 \mathrm{I}$ knots, provided by a two-shaft steam turbine machinery. ${ }^{58} \mathrm{It}$ would have accommodation for up to 700 men and carry i 5 tanks, six self-propelled guns, 50 loaded three ton trucks and ninety tons of stores. The ship would carry four landing craft at davits and embark larger craft in a stern dock. By flooding the dock, loaded landing craft would float out through a stern gate in the same manner as with an LSD or the US Raleigh class LPDs then under construction. Space would be provided on the after-end of the weather deck for the operation of Wessex helicopters. The ship would be fitted out as a Naval Assault Group/Brigade headquarters ship. The only armament provided was to be four Seacat launchers with eight missiles each and two Bofors guns. The Board directed that for any future assault ships, consideration should be given to fitting a 4.5 inch turret in order to provide some self-defence capability against surface attack. The estimated cost of this vessel was $£ 8,750,000$ excluding the cost of craft, stores, ammunition, fuel etc. 59 The contract for this ship, dubbed Landing Ship Assault, was placed with Harland and Wolff at Belfast in December 1961. ${ }^{60}$ The 1962 Navy Estimates noted that the first assault ship had been ordered and announced that a second would be ordered during that financial year. ${ }^{61}$

The first assault ship, HMS Fearless, was launched in December 1963 and commissioned in November 1965. The second ship, HMS Intrepid, was launched at John Brown's Clydebank shipyard in June 1964 and commissioned in 1967. At I 2, I 20 tons full load, with a crew of 580 and capable of 2 I knots the ships could carry 400 troops, I 5 tanks and 27 vehicles and could, in an emergency, embark 700 troops at the expense of some vehicle lift. Capable of carrying a balanced military force on an ocean passage in company with the commando carriers, these ships represented a considerable improvement on the old AW Squadron. Each ship had a flight deck

54 NA CAB I 3 I $/ 24, \mathrm{D}(60) 54$, memo by the Minister of Defence, 2 Dec. 1960.

55 Ibid. NA CAB I 3 I/23, D (60) i 2 th mtg, 7 Dec. I960. NA DEFE 7/1678, D (6r) I 7, memo by the Chancellor of the Exchequer, 20 Feb. 196r.

56 BPP Cmnd I 282, Explanatory Statement on the Navy Estimates 196I-I962 (London, I961)

57 This represented an increase from the original Staff Requirement of 10,000 tons and a sketch design of I I, 540 tons. All tonnages given are for deep displacement. NA ADM I67/1 57, B.I333, Assault Ship: Sketch design, memo by the Controller, 9 May 1960.

58 When decommissioned in 2002 Fearless was the last steam powered ship in the Royal Navy.

59 NA ADM 167/I 59, Board Minute 5482 and Memo B.I 382.

60 NA DEFE 5/I 24, COS (62) 81, 2 I Feb I962, report by Chief of Amphibious Warfare.

6I BPP Cmnd 1629. Explanatory Statement on the Navy Estimates 1962-1963, (London, 1962). 
with facilities for up to five Wessex helicopters and carried four LCVPs at davits and four Landing Craft Utility in their dock. The latter were designed to each be able to land two Centurion tanks or an equivalent load. In the event, neither ship was fitted with a 4.5 inch gun. After I 5 years of valuable service with the Royal Navy they were to display their worth by playing a central part in the successful amphibious landings of the Falklands conflict in $1982 .{ }^{62}$

The assault ships, given the US-style designation LPD, ${ }^{63}$ were supported by six new 5,674 ton Landing Ship Logistic (LSL) launched between I963 and 1967 and designed to replace the WD LSTs. The requirement for follow-on shipping was different to that for the LPDs in that the ships were not required to arrive so quickly and they were not expected to land troops or vehicles in an assault. They were, however, required to carry all of the supporting equipment that would be required by a brigade group and to be able to land their cargo efficiently without recourse to conventional port facilities. The ships would also need to be suitable for use in general military transport duties between operations. After detailed enquiries it was agreed that an improved bow-loading LST was the most suitable vessel. ${ }^{64}$ The factors that made LSTs unsuitable for the assault fleet, primarily limited speed and the difficulty of landing armour in an assault, did not apply to the follow-on force..$^{65}$ All six ships participated in the 1982 Falklands Conflict and continued in British service until replaced from 2006 by the introduction of four new I6,000 ton Bayclass Landing Ship Dock (Auxiliary). ${ }^{66}$

The LPDs and LSLs were built to meet a particular requirement. They were designed to support the assault landing of a balanced army brigade group with supporting arms, including armour and artillery. The LPDs were chosen specifically because of their ability to support a joint all-arms landing force. The requirement to land tanks in an assault had a major impact on the decision to adopt the ATD type design. No other ship type offered the possibility of landing armour in the early stages of an assault while also providing for reasonably high speed on an ocean passage. Design study DL/A, for a vessel capable of embarking I,050 troops, was ruled out as too large and instead design DL/B was adopted, catering for a smaller ship able to take three-quarters of a brigade group (i.e. 700 troops). However, it proved impossible to meet this requirement in a ship of only 8,000 tons and Fearless and Intrepid eventually displaced i 2, I00 tons, 600 tons more than DL/A.

Fearless and Intrepid were not particularly innovative ships. Their basic design owed much to the LSD developed during the war and the US Navy had already

62 NA DEFE 5/I 50, COS 109/64, 2 April 1964. Conway's All the World's Fighting Ships, 19471982. Part One: The Western Powers (London, 1983).

63 In US parlance 'LP' stands for 'Amphibious Transport' and 'D' for 'Dock', hence LPD. In British use LPD has come to mean 'Landing Platform Dock' based on an initial misunderstanding of the US abbreviation. This is intriguing given that the description of these ships in all of the preliminary studies was as Amphibious Transport Docks, an accurate translation of LPD. I am indebted to Professor Eric Grove for clarification on this point.

64 NA DEFE $5 / 87, \operatorname{COS}(58)$ 296, 32 Dec i958. NA DEFE 4/I I 5 , COS (59) ist Meeting, item I0, I Jan. I959.

65 NA DEFE 5/103, COS (60) I 5 I, report by the Shipping Resources Committee, 3 I May I96 I. 66 Sir Galahad, commissioned in 1966, was badly damaged by an Argentine air attack in Jun. 1982. The vessel was replaced by a ship of the same name that commissioned in 1987 . 
refined this concept in their post-war LSDs and with the new Raleigh class LPDs, the first of which commissioned in 1962. Nevertheless, the two British LPDs did help to transform British capabilities providing, with the commando carrier and the LSLs, a robust modern force well suited to the unpredictable demands of British policy. Both ships had eventful careers, providing service from the warm waters of the Indian Ocean to the freezing seas off northern Norway and both played a key role in support of the amphibious operations that made possible the liberation of the Falklands Islands in I982. They were finally decommissioned in 1999 (Intrepid) and 2002 (Fearless), their versatility having provided ample validation of the decision to adopt the ATD type design.

Fearless and Intrepid were built to support a new emphasis within British defence policy on expeditionary forces designed to provide flexible options for military intervention overseas, particularly east of Suez. The Royal Navy embraced the expeditionary role and by 1962 amphibious operations had become their key task, with all other assets justified through reference to it. Of course, the role was particularly useful because it allowed them to advance a case for a balanced fleet, a fleet not too dissimilar to the one that they would have wanted whether or not the amphibious role was so prominent. A key element of this was the plan to replace the existing aircraft carriers with new, larger and more capable vessels by the I970s. In this respect the navy ran into intense opposition from the RAF, who were adamantly opposed to anything that might challenge their primacy in the provision of air power overseas. However, whilst their opposition to the carrier replacement programme was total, the RAF did not show the same hostility to plans for new amphibious ships. Indeed, even as the carrier controversy gained pace, the Chief of the Air Staff, Air Marshal Sir Thomas Pike, suggested in I96I that the navy might accept a smaller 'close support carrier', soon dubbed the Pike-ship, that would combine the role of commando carrier and light aircraft carrier. ${ }^{67}$ The suggestion was motivated more by a desire to push the navy away from the large carriers that they favoured than by any inherent belief in the value of amphibious forces, and it should be noted that the commando carriers provided a similar type of capability for small scale intervention by light forces that was favoured by the Air Force. Nevertheless, the Pike-ship concept, and subsequent RAF interest in a similar proposal by Minister of Defence Peter Thorneycroft two years later (dubbed the Thorneycraft) does illustrate a willingness to countenance further enhancements to the navy's amphibious capabilities once these were not linked overtly to support for new large carriers. ${ }^{68} \mathrm{It}$ is significant that the debate over the replacement of amphibious shipping occurred in the late 1950s before the carrier controversy really ignited. The ships supported a concept of operations at odds with that preferred by the RAF and for which the RAF consistently argued against, but the army and the navy were united in thinking these ships necessary and they were supported in this by the Minister of Defence.

By the time that Fearless and Intrepid were operational the role for which they had been built had begun to disappear as the British withdrew from east of Suez. However, and unlike the ill-fated new carrier, they were already built and represented a considerable investment of capital and thus they survived the cuts of the Labour

67 NA AIR 8/2328, COS (6I) 358, 29 Sep. I96r.

68 See NA DEFE 4/52, COS I6 mtg/63, 26 Feb. I963; NA ADM 205/I94; NA AIR 20/I I 423 and NA AIR 8/2354. 
Chancellor, Denis Healey, finding a new role in colder waters closer to home. In the event the change in British policy meant that the ability to land heavy armour in an assault did not figure prominently in the careers of these two ships. However, the inherent flexibility built into their design by the need to meet this requirement served them well in a wide variety of different circumstances and it is significant that their replacements, two I 8,500 ton Albion class LPDs, follow broadly similar design principles. In retrospect it appears that the navy, with army support, did a good job when replacing the AW Squadron.

\section{Appendix A}

Figures I to 7 show the sketch designs for the different ship types considered in the report on the Technical Examination of the Problem of Replacement of the Assault Lift by the Admiralty Assault Study Group, I3 November 1958.69 The report concluded that the best choice appeared to be either BL/D (figure 5) or DL/B (figure 7) and ultimately the latter provided the basis for future planning. 

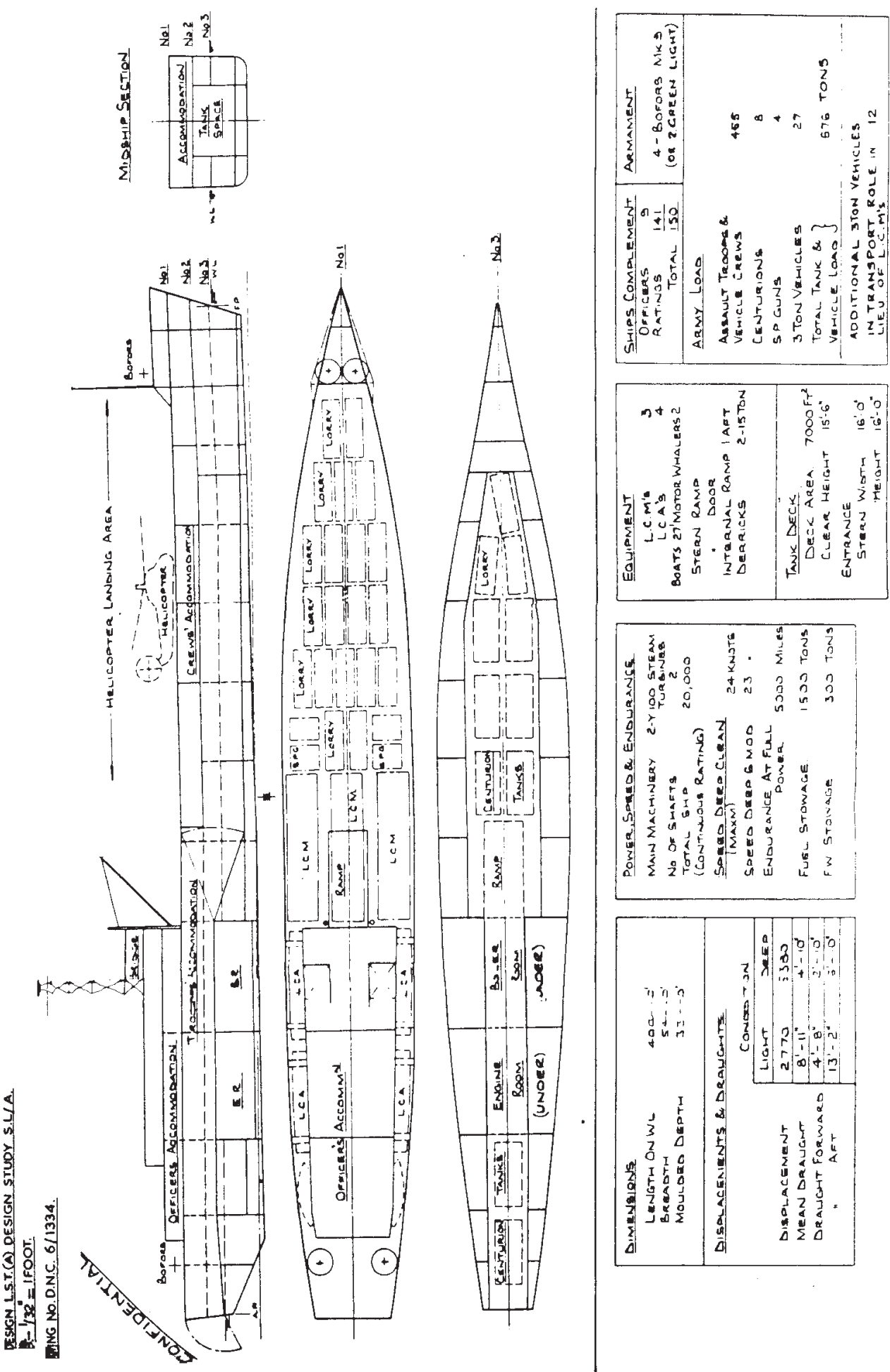

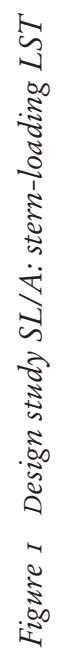



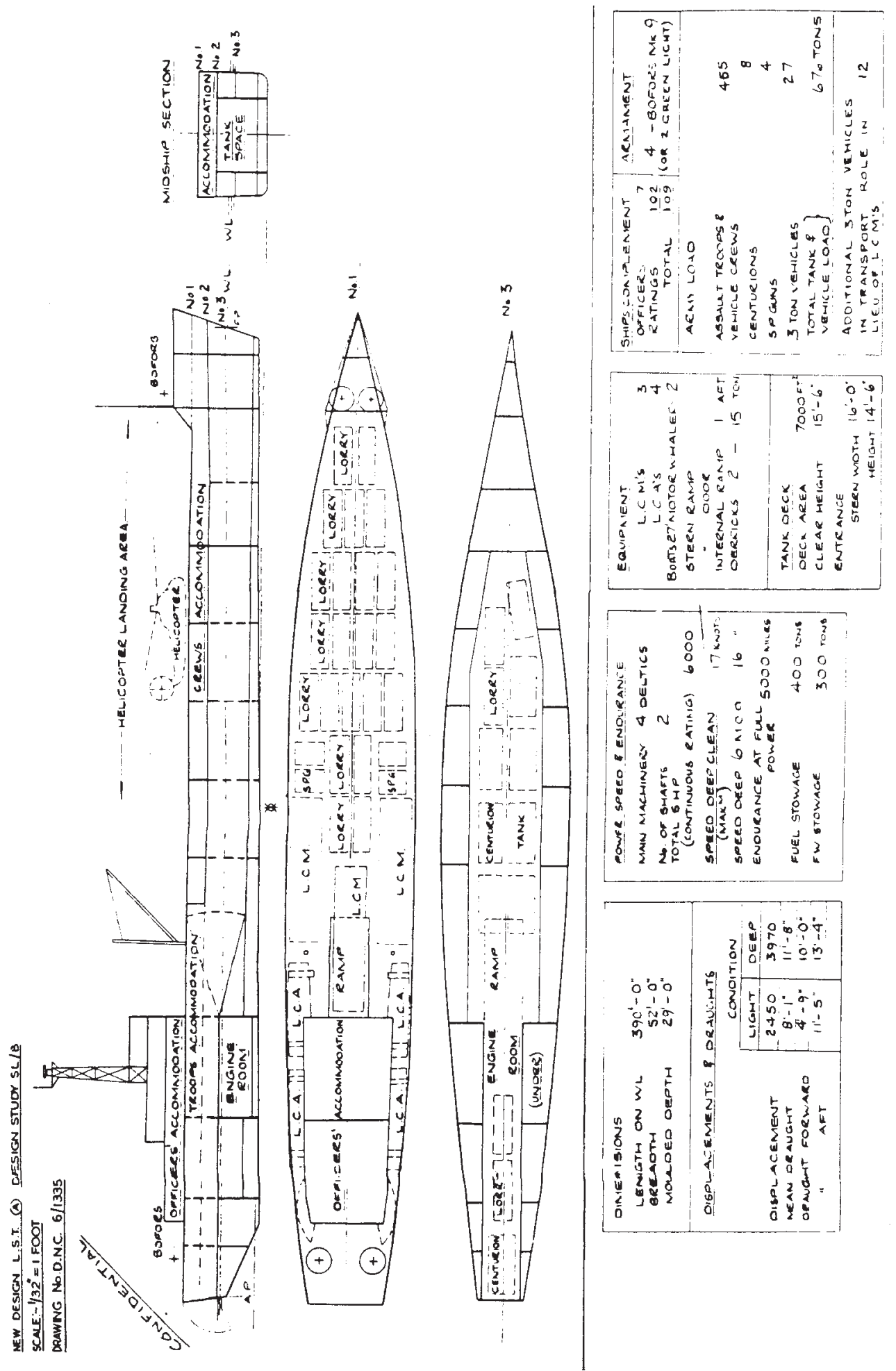

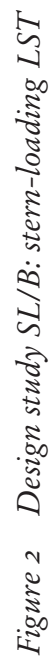



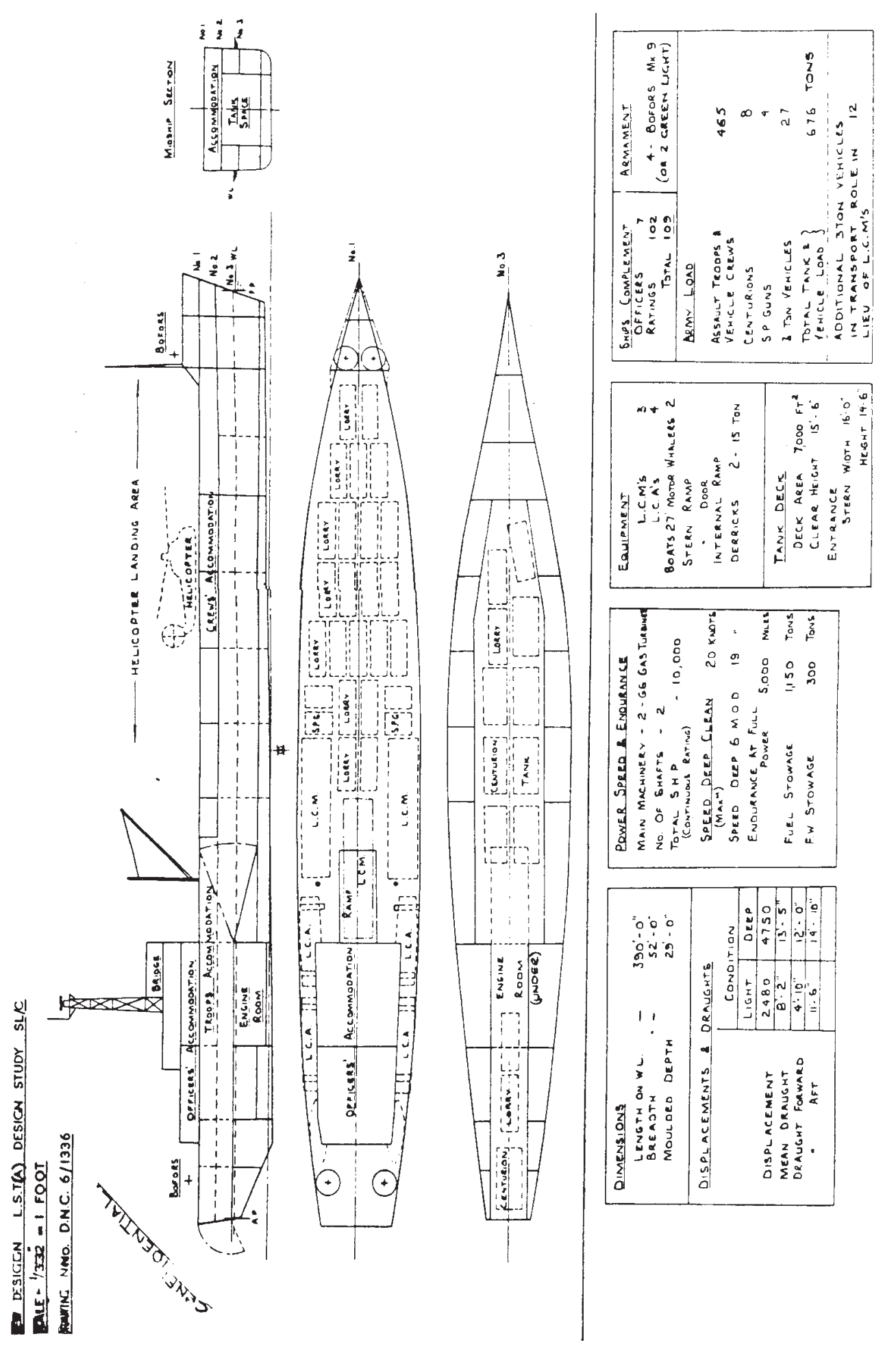

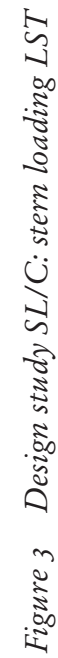



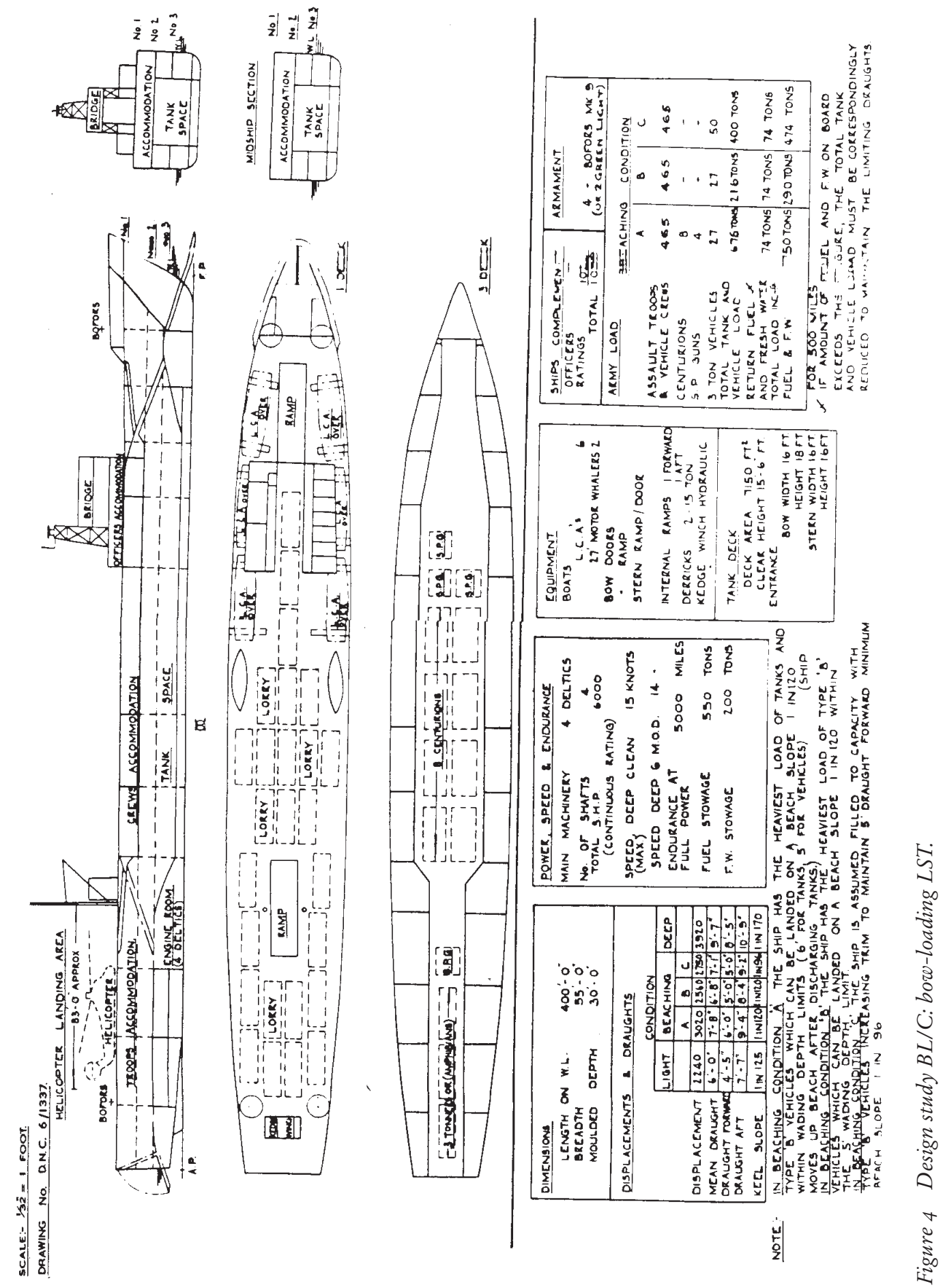

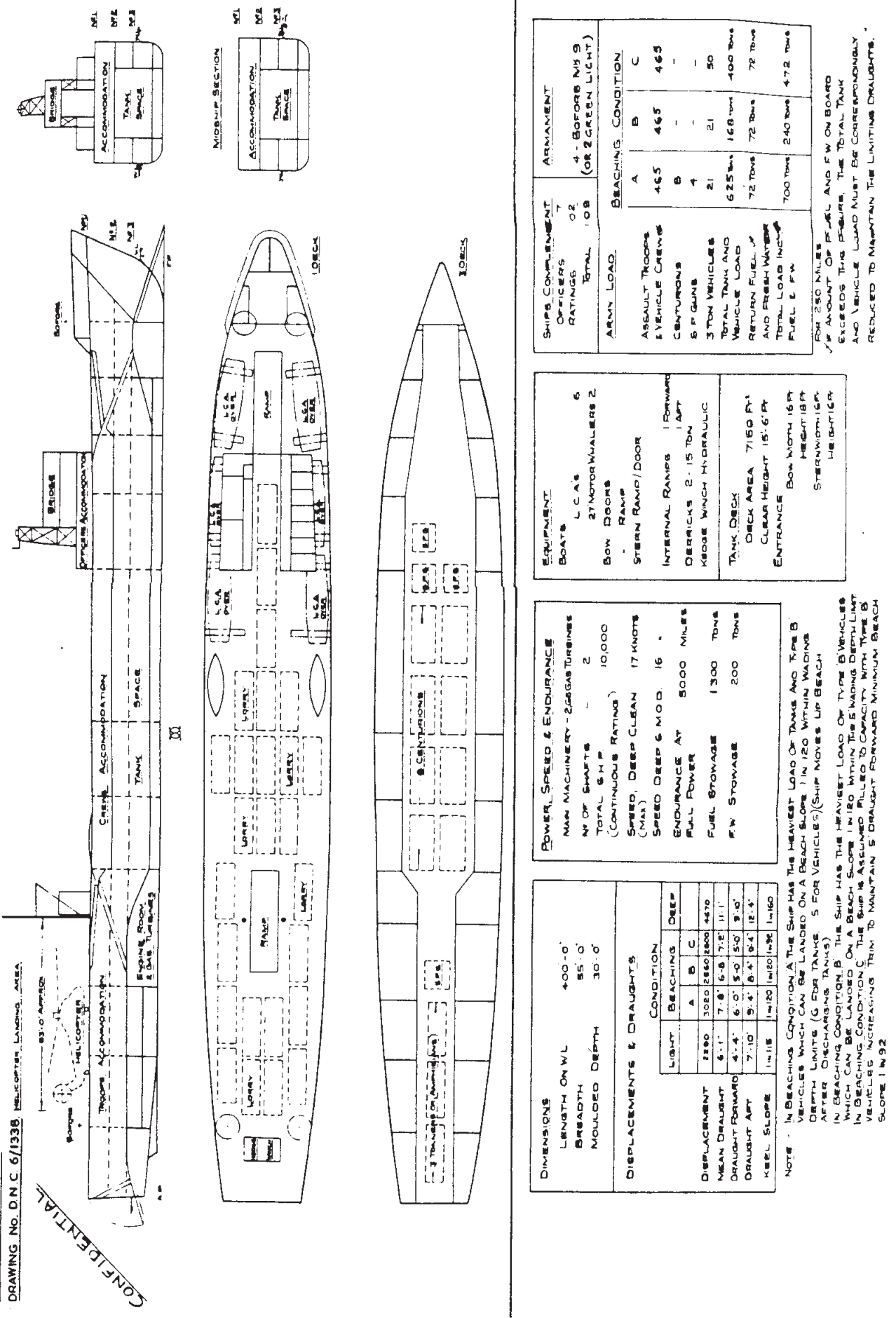

5
5
0
0
5
5
0
0
5
0
0
0
$\vdots$
0
3
5
0
0
0
0
0
0

ญ 


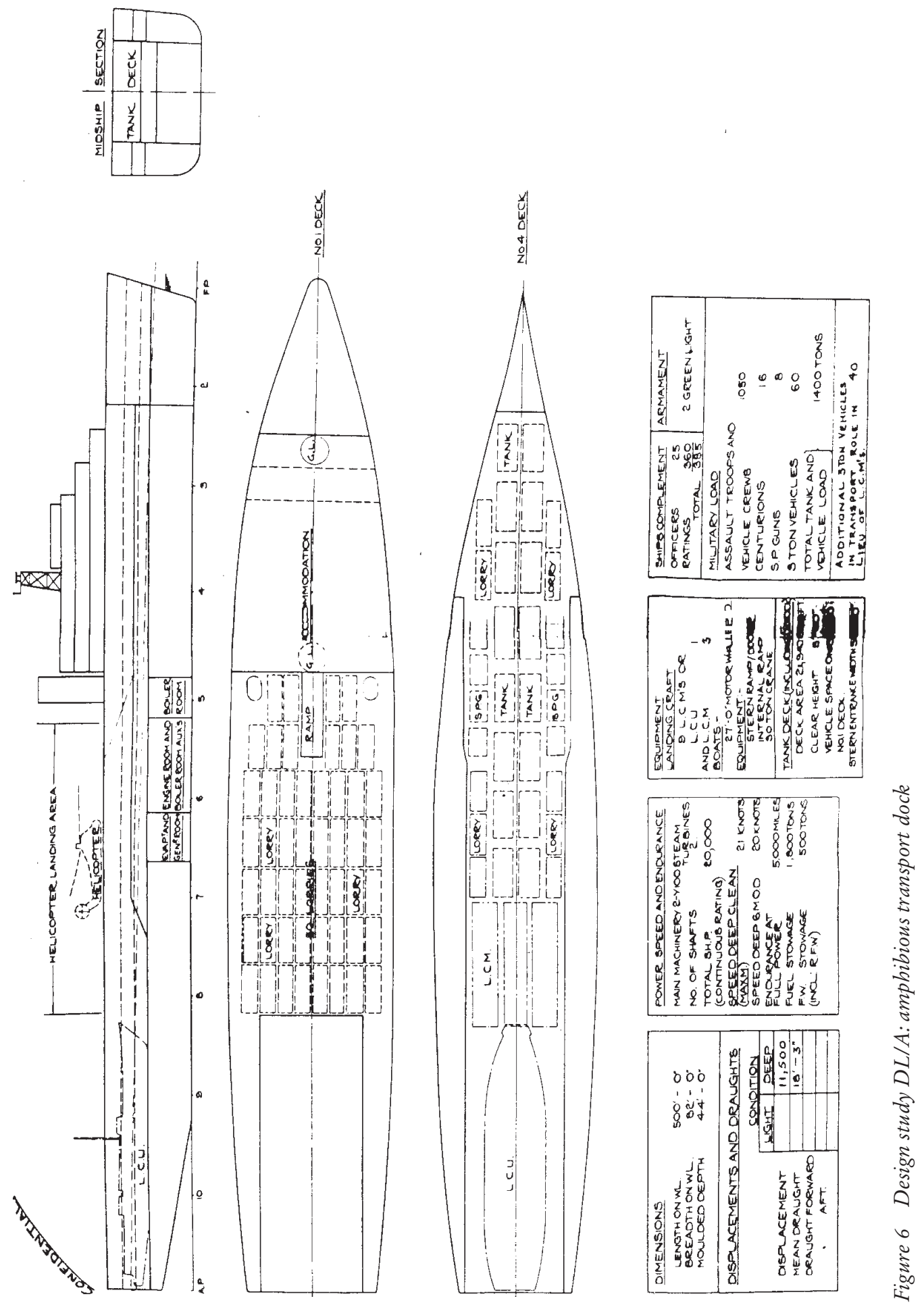



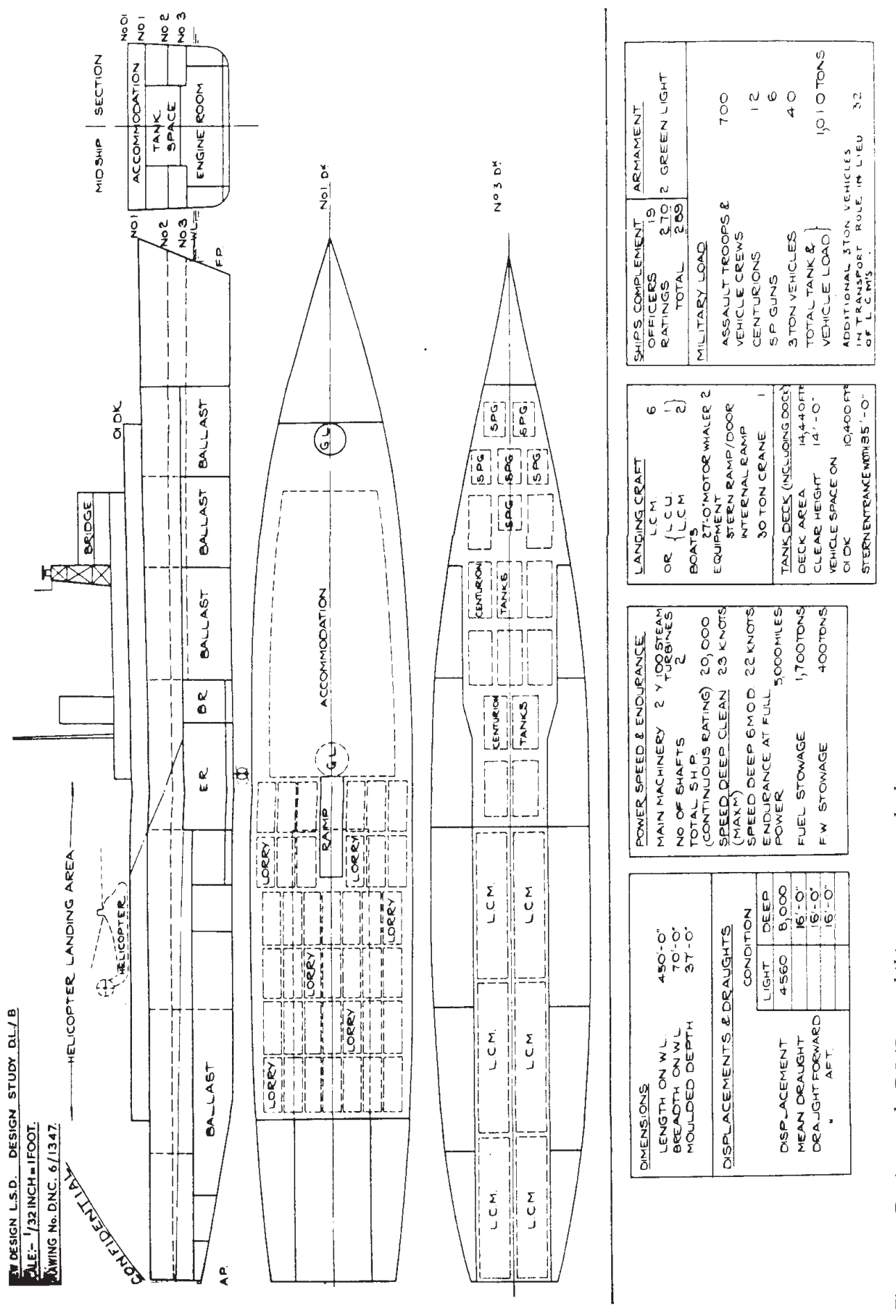

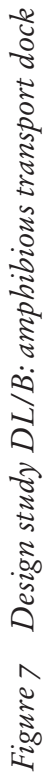

